\title{
Reforming mathematics learning in Indonesian classrooms through RME
}

\author{
Robert K. Sembiring $\cdot$ Sutarto Hadi • \\ Maarten Dolk
}

Accepted: 29 July 2008/Published online: 23 August 2008

(C) The Author(s) 2008. This article is published with open access at Springerlink.com

\begin{abstract}
This paper reports an experimental study on the development of exemplary curriculum materials for the teaching of fractions in Indonesian primary schools. The study's context is the current reform movement adopting realistic mathematics education (RME) theory, known as Pendidikan Matematika Realistik Indonesia (PMRI), and it looked at the role of design research in supporting the dissemination of PMRI. The study was carried out in two cycles of teaching experiments in two primary schools. The findings of the design research signified the importance of collaboration between mathematics educators and teachers in developing RME curriculum materials. The availability of RME curriculum materials is an important component in the success of the PMRI movement, particularly in supporting students and teachers in activity-based mathematics learning. Most of the students and teachers in the two schools positively appraised teaching and learning with the developed materials. Since the teachers were actively involved in developing the materials, they felt a sense of ownership and recognised that their students' classroom experiences of the materials helped them avoid standard difficulties. That appears to be a particular benefit of the bottom-up approach characteristic of the PMRI movement.
\end{abstract}

R. K. Sembiring

Leader of the PMRI Team, Bandung, Indonesia

e-mail: epamitb@indosat.net.id

S. Hadi $(\bowtie)$

Department of Math Education, Lambung Mangkurat

University, Banjarmasin, Indonesia

e-mail: shadi@fkip.unlam.ac.id; sutarto_hadi@yahoo.com

M. Dolk

Freudenthal Institute, Utrecht University, Utrecht,

The Netherlands

e-mail: m.dolk@fi.uu.nl
Keywords Realistic mathematics education . Dissemination · Sustainability · Pedagogy · Teacher learning

\section{Introduction}

There is a growing awareness among scholars in Indonesia of the need to improve mathematics teaching in schools. Since 1996, a group of concerned educators in the country has attempted to improve mathematics education in primary schools. Concerns were frequently expressed publicly, particularly after Indonesia abandoned modern mathematics. It is acknowledged that modern mathematics, which had been implemented since the beginning of 1970, resulted in a problematic situation in schools. Several studies have shown the weaknesses of mathematics teaching in primary education: students find it difficult to comprehend mathematical concepts and to construct and solve mathematical representation from a contextual (or story) problem, and the teaching style makes mathematics more difficult to learn and to understand. Students have also become afraid of mathematics (Haji 1994; Jailani 1990). The results of national leaving examinations showed that mathematics was continuously the lowest-scoring subject (Depdikbud, 1997). Given those facts, the question of what should replace the traditional teaching arose, and after considerable research realistic mathematics education (RME) was chosen as the development strategy for Indonesia's new paradigm of mathematics education.

Realistic mathematics education approaches to school mathematics are widely recognised as providing one of the best and most detailed elaborations of the problem-based approach to mathematics education (Hadi 2002). Originally 
developed in the Netherlands, RME theory has been used in several schools in the United States of America (USA) as part of a collaborative project, Mathematics in Context (MiC), between the Freudenthal Institute (FI), Utrecht University and the University of Wisconsin. The data indicate that this international collaboration has been a worthwhile enterprise, in that 'the wisdom of practice' of many years in the Netherlands has been used as a startingpoint for curriculum development in the USA. (Clarke et al. 1996; de Lange 1994). After students in several school districts from different states used the materials, preliminary research showed that the students' achievement in national tests greatly increased (Romberg and de Lange 1998). In the Netherlands, there are also positive results from the use of RME curriculum materials. The Third International Mathematics and Science Study (TIMSS) results showed that students in the Netherlands scored highly in mathematics (Mullis et al. 2000).

Inspired by the philosophy of RME, one group, later called the Pendidikan Matematika Realistik Indonesia (PMRI) Team, developed an approach to improve mathematics learning in Indonesian schools. It is known as PMRI, an Indonesian adaptation of RME. It was developed through design studies in Indonesian classrooms, later becoming a movement to reform mathematics education in Indonesia. The movement does not just implement a new way of teaching and learning mathematics, but is associated with a drive to achieve social transformation within Indonesia. The approach to reform adopted by PMRI involves:

- bottom-up implementation;

- materials and frameworks based on and developed through classroom research;

- teachers being actively involved in designing investigations and developing associated materials;

- day-by-day implementation strategies that enable students to become more active thinkers;

- the development of contexts and teaching materials that are directly linked to school environment and the interests of students.

Fundamentally, PMRI uses bottom-up strategies, with its approaches and materials being largely developed in the classroom rather than behind the desks of curriculum officers. Mathematics education reform in Indonesia has been initiated in classrooms and teachers have changed their mathematics teaching approaches as a result of their involvement with new materials, textbooks, investigation, experiments, in-service education and in-class training. These classroom experiments have not only provided the base for the development and refinement of PMRI theory, but have also informed those involved in the development of courses for teachers and the writing of student textbooks and accompanying teachers' guides.

Within Indonesia, PMRI not only provides a new approach to teaching mathematics, but also a new way of thinking about the purpose and practices of school mathematics. That said, it also needs to be recognised that it has not been easy to implement PMRI theory and approaches in the teaching and learning of mathematics in Indonesian schools. First, the PMRI approach to teaching is at odds with the well-established Indonesian practice of teachercentred, whole-class teaching and the assumption of transmission of knowledge.

Many commentators on Indonesia's schools believe that most innovations introduced into the schools over the past few decades have had no significant impact on the quality of education. It was therefore assumed, by many observers, that the PMRI approach would not capture the minds of teachers, and would not greatly influence their classroom practices. The reality has been quite different, however. Although some teachers have not embraced PMRI's philosophies, and have not adopted the recommended teaching approaches, these are in a minority, and most have developed positive perceptions of PMRI, and have come to view it as an alternative method likely to be needed in mathematics reforms in school. These teachers have grown to accept PMRI's philosophy that teachers should guide students towards reinventing mathematical concepts. Nevertheless, there are some who think the PMRI approach is too radical and is therefore unlikely ever to be accepted by the majority of the nation's teachers.

The PMRI team realised that in order to be successful in implementing PMRI, teachers and students needed curriculum materials that were consistent with Indonesian ideals and contexts. The materials needed to be grounded in and supportive of student thinking, and be able to help teachers guide students towards reinventing mathematical concepts. They should support teachers in organising rich learning activities in classes in which there is a large diversity of student backgrounds. Clearly, the activities and contexts chosen needed to be easily recognised by students, and the language and diagrams needed to be simple and clear, so that they gave maximum support to the development of mathematical concepts (Hadi 2002). One possible approach to fulfilling these requirements was for curriculum developers and textbook writers from the universities to work with the teachers. In Indonesia, however, the difference in status between university lecturers and primary school teachers was clearly a stumbling-block. How could people with such different backgrounds learn to work together profitably on research, so that they communicated and exchanged ideas and experiences fruitfully? 


\section{Mathematics learning in primary education in Indonesia}

This part begins with a description of the state of the art of Indonesian mathematics education and the need for reform. We also discuss RME as the inspiration for PMRI.

\subsection{State of the art of Indonesian mathematics} education and the need for reform

The population of Indonesia is currently about 240 million, of whom about 25 million are primary-school-age children. The participation rate in schooling is estimated at around $85 \%$. Across the nation there are currently about 145,000 primary schools-not including private and Islamic schools-with 1,235,000 teachers.

Primary school teachers are mostly graduates of SPG, a senior high school-level institution that accepts students from lower secondary schools for a 3-year course. In 1991 the government decided to increase the education level to a 2-year diploma course (D2) following upper secondary education. This D2 education is conducted by the Institute of Teacher Education (ITE). In 1995 the level of education for intending primary teachers was raised to that of a first strata university graduate. This PGSD (Teacher Education for Primary School) programme was established in many ITEs (Armanto 2002), and from 2007 a system of certification has been applied to all teachers in the country.

In 1973 the Indonesian government replaced arithmetic with modern mathematics as a curriculum subject in primary schools, but this change has proved to be problematic, as mentioned in the beginning of this paper. Many teachers came to believe that modern mathematics was too difficult for their students, and often teachers taught in ways that relied almost totally on textbooks. In the classroom they followed the textbook page by page, without considering the correctness or otherwise of the mathematics that students wrote in their books (Somerset 1997). As a result, the teaching and learning of mathematics in Indonesian schools became mechanistic, with teachers tending to dictate formulas and procedures to their students (Armanto 2002; Fauzan 2002; Hadi 2002).

For more than three decades a teaching-as-telling method influenced students' attitudes. Students were expected to learn mathematics in passive ways and, but some hardly learned it at all. Many students became used to being spoon-fed by their teachers, and were rarely asked to think creatively or critically about what they were learning. The following is an extract from an observation in a primary school in Surabaya (East Java) that illustrates the common way of mathematics teaching in Indonesia (Fauzan 2002, p. 2).
Teacher: OK students, today we are going to learn about multiplication of two digit numbers by two digit numbers. Please pay attention to what I am going to explain, otherwise you will not understand this lesson.

The teacher writes a problem of multiplication of twodigit numbers on the blackboard and starts solving it by himself. In solving the problem, the teacher does it by talking and writing simultaneously. Sometimes he asks the students as a whole the result of a step in the solution, and the students give the answers in chorus. The teacher makes a response by saying 'good' whenever the students come up with the right answers, but he does not comment if the responses are wrong. He then finishes solving the problem.

Teacher: Do you understand what I explained?

Students: Yes (some students answer in chorus, and the rest are silent)

Teacher: To make it clearer, I will show you another example.

He repeats the process, and at the end he asks the same question to check if the students understand or not. The 'yes' sounds louder and the teacher seems to be satisfied. He continues:

Teacher: Now open your textbook page ... then solve the exercises ... number ... the same way as I just showed you.

Research conducted by Armanto (2002) revealed the effect of this teaching style. He observed several misconceptions on the part of the students doing the procedures after learning the standard algorithm. Some teachers argue that by learning the procedures of the standard algorithm, the students can understand and apply algorithms easily to solve other problems. This argument is hardly true because in answering a multiplication contextual problem set by the teacher in the following example, only one-third of students can solve the problem correctly, and most of them have difficulties with the idea of multiplication algorithms. A conversation with one of the students gives an indication of this misconception (Armanto 2002, p. 4) (Fig. 1).

Observer: Did you find the answer?

Student: Yes, sir. This is my calculation.

Observer: Why did you calculate like this?

Student: Because the teacher taught me to do that.

Observer: Why did you multiply $7 \times 5$ in the first

place and not $3 \times 5$ ? (The observer points to the numbers of multipliers).

Student: Because 7 is the last number of 37 and the teacher showed me to multiply it first.

Observer: The multiplication of $3 \times 5=15$. Why did you put 5 (from 735 ) under the second 1 of 1715 ? 


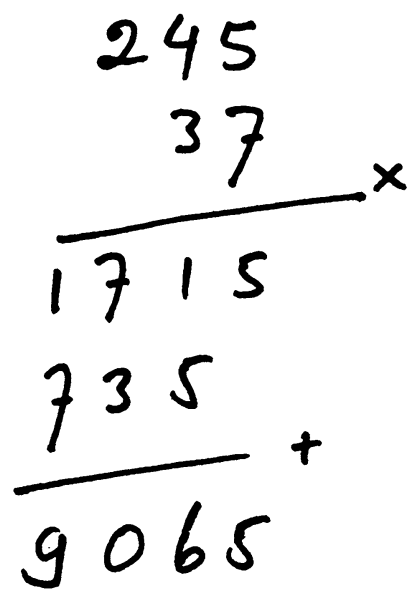

Fig. 1 The Students' valid procedure

\section{Student: I don't know. The teacher did that. I think I should follow her, and it works. I got the answer.}

Many Indonesian mathematics educators felt that this top-down, 'traditional' teaching approach to school mathematics not only adversely affected students' perception of mathematics but also their achievement in national examinations. It was often claimed that many students had developed 'mathematics phobia', and their anxiety about mathematics was believed by some to be responsible for low achievement. In national examinations from 1990 to 1997, junior secondary school students' average scores for mathematics were always below 5 on a 10-point scale, making it consistently the lowest-scoring subject of all those taught in school (Manan 1998). In international comparative studies like TIMSS and PISA, Indonesian students performed below most other participating countries.

A transition from a more traditional, skill-oriented approach towards a problem-based, reform approach to school mathematics in Indonesia would constitute a major and complex transformation. It would require not only the introduction of new instructional sequences and activities, but also new roles for the teacher and new social and sociomathematical norms. It would be the teachers' responsibility to foster a problem-solving classroom culture which challenged students to move on from their current, more passive, receptive roles towards more active, participatory roles. The students would need to take the initiative, and learn to think and reason for themselves. In addition, teachers would have to learn to guide the new learning process by choosing or designing instructional tasks that generated productive mathematics thinking at any given time. They would need to organise and orchestrate wholeclass discussion that helped students to think creatively. The role of the teachers would consequently need to change from an authoritarian, instruction-oriented orientation towards a more supportive, student-centred and constructivist orientation. Obviously, in-service and pre-service teacher education would have to be a key component of the reform process. Co-teaching in classrooms would need to become much more commonplace, as would the production of supportive textbooks and teacher manuals. The expectation that the intended innovation would fit Indonesian education and social contexts would also be important. In this respect, an important prerequisite for success would be the development of a sense of ownership by the teachers and teacher educators who would be involved. A bottom-up approach was therefore called for, in which Indonesian teachers and teacher educators reinvented a form of RME that fitted Indonesian contexts and priorities.

\subsection{Why RME?}

There are three basic tenets of RME, namely guided reinvention, didactical phenomenology and the mediating models principle. All these tenets are inspired by Freudenthal's view of 'mathematics as human activity'. This notion places a heavy emphasis on students' activity in their reconstruction of mathematical ideas and concepts under the guidance of the teachers.

The guided reinvention principle surfaced in response to teaching 'mathematics as a ready-made system', where the end-results of the work of mathematicians are taken as the starting-point of mathematics teaching. In Freudenthal's view $(1973$; 1991) mathematics should be undertaken as an activity in which students experience mathematics as a meaningful subject and can better understand it. Mathematics should therefore not be presented as ready-made. The guided reinvention principle puts importance on mathematics as a process in which students learn mathematics in activities guided by their teachers or their peers.

The didactical phenomenology principle concerns finding contextual problems and situations that allow generalisations and provide a basis for linking solutions to concepts or ideas in mathematics. According to Gravemeijer (1994, 1999), the goal of a phenomenological investigation is to find problem situations for which situation-specific approaches can be generalised, and to find situations that can evoke paradigmatic solution procedures that can be taken as the basis for construction of formal mathematics.

The mediating models principle describes the role which the constructed model plays in bridging the gap between informal knowledge and formal mathematics (Gravemeijer 1994). Models are first linked with the contextual problems and then, by gradually solving similar problems, students will be led to more formal mathematics. Ideally, models in RME emerge from students' own activities and then gradually serve as a catalyst for a growth process to more formal knowledge (Gravemeijer 1998). Gravemeijer noted that it is 
not always possible to have students reinvent models on their own. Sometimes, models are given to students but in that case these models should support the transition of students' thinking about more formal mathematics.

The theory of RME is useful in several countries, such as in the Netherlands and the USA. Much more important than this, however, is that the concept of RME is itself in line with the current thinking in Indonesia about mathematical learning which emphasises student-active learning, problem-solving and the application of mathematics.

It is a common belief in Indonesia that the objective of teaching and learning mathematics is to develop students' reasoning and logical ability. If we carefully listen to the messages from mathematics teachers in Indonesia, then one of their concerns is how to make mathematics lessons relevant to students in dealing with everyday problems (Zamroni 2000). It is also argued that mathematics should be mastered as a systematic pattern of reasoning (Nasution 1996). The (re)construction of mathematical ideas and concepts goes hand-in-hand with the process of the development of students' reasoning ability. This can be achieved in RME through students' exposure to contextual problems within the framework of an interactive teaching and learning process.

In the initial phase of RME implementation in Indonesia, several pieces of research have been conducted, e.g. research by Armanto (2002) on prototyping of local instructional theory on multiplication and division, and that by Fauzan (2002) on the development of RME exemplary curriculum materials for the teaching of area and perimeter. Both studies showed that the RME materials had a positive influence on the students.

Furthermore, research conducted by Hadi (2002, p. 215) indicated that Indonesian teachers could implement the RME materials after they were properly trained. There were noticeable changes in teachers' lesson structure during and after in-service training. The results of classroom observations during classroom practices indicated teachers' ability to translate RME principles into classroom lessons. With the support of RME exemplary curriculum materials (student's book and teacher's guide) the teachers could perform instruction that was different from their usual practice (Fig. 2).

In their daily practice, teachers perform their lesson following this sequence: opening-example-exerciseclosing. Their lesson structure was dominated by traditional 'chalk and talk' that put intellectual authority in the hands of the teachers, and limited students' activities to note-taking. This unfortunate nature of the 'traditional' learning process makes students into passive learners with little aptitude for mathematical thinking and reasoning.

In the classroom practice during and after the in-service training programme, teachers tried to structure their lessons

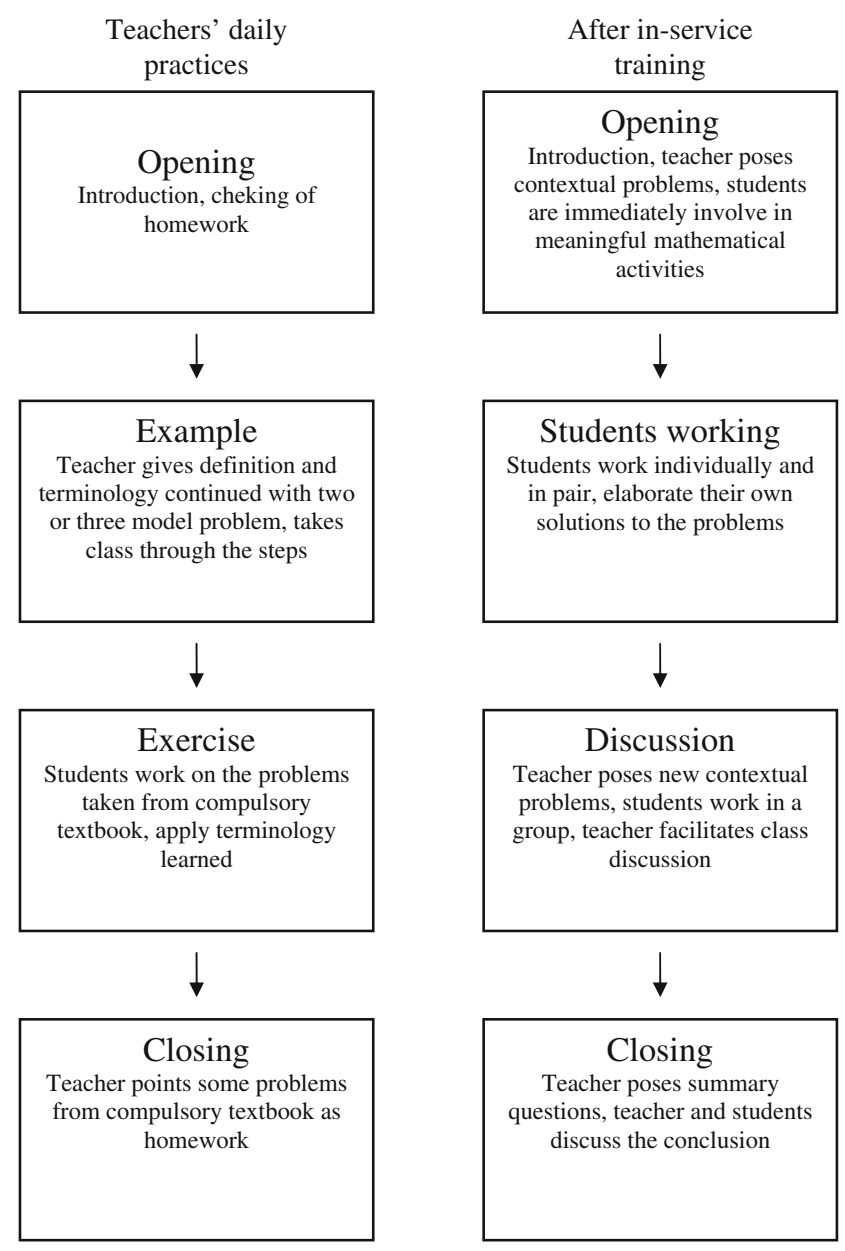

Fig. 2 Teachers' mathematics lesson structure

by emphasising the students' learning. Although it was rather difficult because the students were used to being spoon-fed, the teachers always asked their students to explain their thoughts, or commented on their response, or facilitated discussion.

Current thinking in Indonesia is influenced by the philosophy of RME, and Widjaja (2008) conducted design research in developing an instructional sequence on decimals to promote Indonesian pre-service teaching' content and pedagogical knowledge on decimals. The research was carried out in two cycles of teaching experiments involving 258 pre-service primary and secondary teachers in an ITE. Pre-service teachers in both cycles are reported to have made substantial improvement in both content and pedagogical knowledge and they gained their first experience of working with physical models and working in groups with class discussion. The findings of the research were helpful in informing the reform movement of mathematics education within the framework of PMRI.

All these RME studies explored the extent to which the RME approach could be utilised in Indonesia and stimulate 
reform in Indonesian education. The results of these studies indicate that if the RME materials are properly prepared and properly taught the RME approach works in Indonesia.

\section{Design studies and content development of PMRI}

In this part of this paper we elaborate on the role of design research in supporting the implementation of PMRI. As mentioned earlier, the implementation of PMRI cannot be done without the availability of PMRI curriculum materials relevant to Indonesian contexts. Design research will not only support the development of Indonesian-based PMRI materials, but will also provide a scientific basis for PMRI. Furthermore, it can be instrumental in overcoming the problem of distance between lecturers and teachers. We will begin with a description of design research. This is followed by an example of what has happened with respect to a particular mathematical concept that Indonesian students find difficult-fractions. Finally we describe a framework for developing PMRI curriculum materials, and the result of an experimental study.

\subsection{Design research}

As an important part of the PMRI project was to develop exemplary curriculum materials, a key research question became: can we expect, by developing such materials, that the dissemination of PMRI (DO-PMRI) will become more effective in supporting Indonesian primary school teachers?

To address this question, a design research method was chosen. Design research is a systematic study of designing, developing and evaluating instructional programmes, processes and products that must meet the criteria of validity, practicality and effectiveness (van den Akker 1999; Seels and Richey 1994). Design research can be classified into two types, depending on its purpose and the time the design process takes place, that is, formative research and reconstructive studies (van den Akker 1999).

At the formative stage, researchers developed curriculum materials based on local instructional theory. Following classroom experiments, these materials and theories were developed to an exemplary level. In teaching experiments, the teachers developed learning trajectories as sequences of activities that were carried out by the students (Armanto 2002; Fauzan 2002; Gravemeijer 1994).

This development was done by designing and testing learning activities in real situations on a daily basis. During the teaching experiments researchers carried out anticipatory thought experiments, in which they anticipated both how the proposed instructional activities might be realised during the interactions in the classrooms and what the students might learn as they engaged in the activities. Both teaching experiments and thought experiments gave useful information for the revision of curriculum material prototypes. Through careful reflections and on the basis of empirical findings, learning trajectories were developed and revised (Fig. 3).

\subsection{Problems in teaching fractions}

The teaching and learning of fractions and decimal numbers have long been problematic in mathematics education in many countries, particularly in primary schools. It is well known that many students struggle to carry out simple calculation involving fractions. Results of a diagnostic survey conducted by the Indonesian Ministry of Education (Somerset 1997) have revealed the following problems. It is known that nearly $30 \%$ of junior secondary students (aged about 13) add the fractions $1 / 4$ and $2 / 5$ simply by adding the numerators and adding the denominators-so that they get the wrong answer, 3/9. Furthermore, most students lack understanding of decimal number values. Apparently, less than one Indonesian junior secondary school student in six can correctly place the three decimals $0.55,0.8$ and 0.14 in order of size from smallest to largest. There are many widespread, systematic errors. For example, more than two-thirds of the students consider 0.8 to be smaller than 0.14 , because they evaluate decimal numbers as if they were whole numbers.

Research conducted by the National Assessment of Educational Progress (NAEP) in the USA has revealed that many USA fourth-grade students also have limited understanding of fractions (Kouba et al. 1997), and, often, a mature understanding requires more than merely getting correct answers to narrow tasks. Thus, for example, students' understanding of the fundamental concept of equivalent fractions should reflect more than mere knowledge of a procedure for generating equal fractions. Students should develop rich connections between symbols, models, pictures and contexts. Only $42 \%$, however, of USA fourthgraders in the NAEP sample chose a picture that represented a fraction equivalent to a given fraction, and only

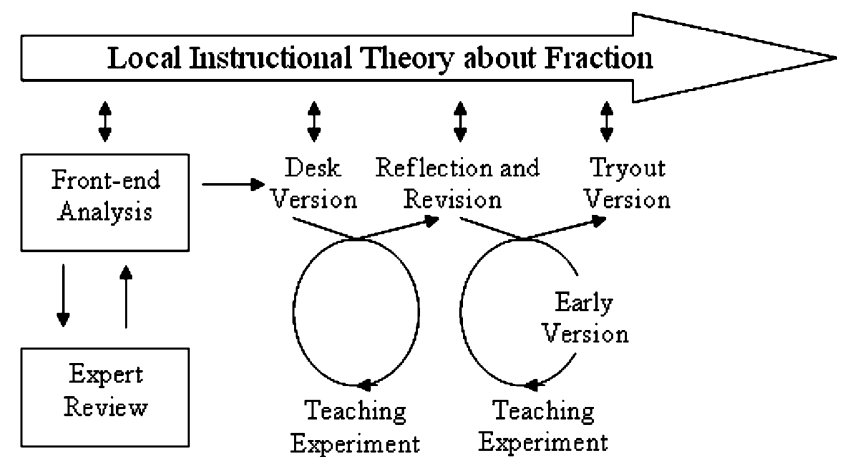

Fig. 3 The construction of local instructional theory 
$18 \%$ shaded a rectangular region to produce a representation of a given fraction (Cramer et al. 2002).

Student difficulties with elementary mathematical concepts can often be traced to the use of inappropriate curriculum materials. Many books, especially commercial ones, used by teachers do not succeed in adequately developing students' mathematical thinking, because they overemphasise drill responses and fail to emphasise connected comprehension of mathematical concepts and ideas (Cramer et al. 2002). The following Fig. 4 is an example of the teaching of fractions in an Indonesian primary school mathematics textbook (Tim Bina Karya Guru 2000) that is widely used. These pages from the book show how to add $1 / 2$ and $1 / 3$ using two methods, i.e. by using equivalent fractions $(1 / 2=3 / 6$ and $1 / 3=2 / 6)$, and finding least common multiples of the denominators of two fractions (1.c.m. of 2 and 3 is 6). The book overemphasises the procedure for solving problems to the detriment of students' reasoning and understanding of mathematical concepts.

\subsection{The framework of PMRI curriculum materials development}

The research reported in this section of the paper was conducted with the purpose of developing exemplary curriculum materials on fractions, based on RME theory. From the development of such exemplary materials it was expected that the teaching and learning of fractions would become meaningful and would support students' comprehension of mathematics, would enable them to use mathematics to solve everyday problems, and would prepare them to study mathematics at a higher level. In the design phase the researchers set the following goals for the framework:

- It should promote students' knowledge and comprehension of fractions using simple and familiar contexts;
- It should contain basic competences as mentioned in the Indonesian primary school mathematics curriculum;

- It was to be designed in themes;

- It should promote students' interactivity in their own reconstruction of mathematical ideas and concepts under the guidance of the teacher.

Apart from the above aspects, this design phase accommodated the basic tenets of RME and was carried out through a review of literature and published RME materials. After considerable investigation, the researchers chose MiC textbooks from the units of 'Some of the Parts', 'Measure for Measure' and 'Per Sense' for adaptation.

In designing content and activities the researchers also referred to a didactical framework proposed by Hadi (2005a, 2005b). The framework, which is illustrated in Fig. 5, was constructed for the purpose of the developing and disseminating PMRI. It could be used as a guideline for developers (scriptwriters) designing PMRI exemplary curriculum materials. The didactical framework consists of several components within education: students, contextual problems, teachers, learning environment and learning experiences. It is an integrated system in which those components are effectively and efficiently intertwined with each other and with the students as the centre of instruction. The developer would be expected to remember that the objective of the instruction was to develop students' understanding of mathematical concepts and ideas by using contextual problems and by student exploration based on a reinvention process (Gravemeijer 1994). Contextual problems are expected to meet relevance and familiarity conditions-specifically, the level of difficulty of problems should be consistent with the level of students' thinking, and the contexts chosen should be well recognised by them (Hadi 2002). The role of the teacher as a facilitator is
Fig. 4 Sample of Indonesian primary school mathematics textbook-adding two fractions

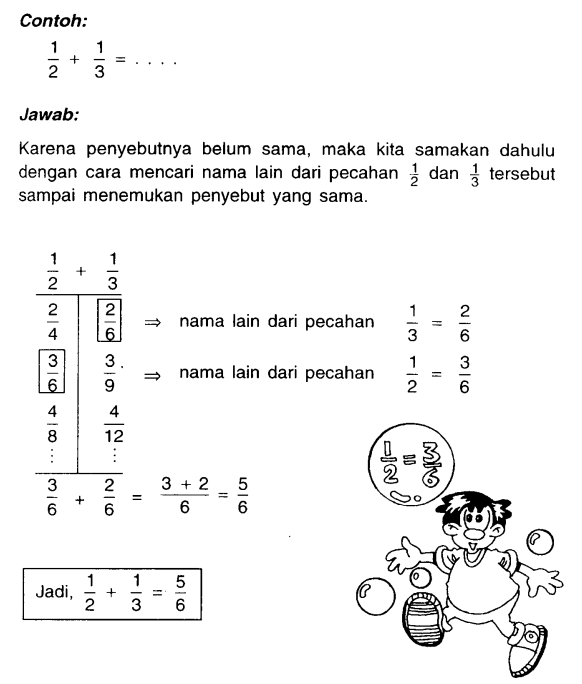




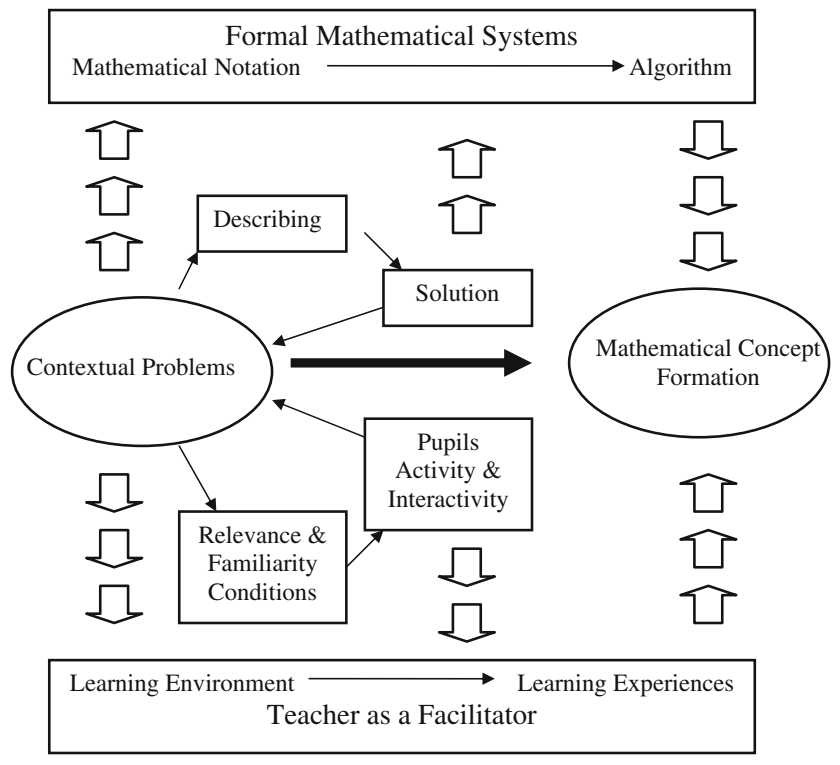

Fig. 5 Didactical framework of PMRI

indicated by his/her ability to build students' thinking processes through an interactive learning environment.

The didactical framework (Fig. 5) contains three kinds of relationships, visualised by three types of arrows, namely bold, block and line arrows. The bold arrows in the middle of the figure depict the main PMRI concept that the learning process should be started by asking students to solve various contextual problems. By doing so, students will immediately and meaningfully become involved in the learning process. The purpose of the contextual problems is to help them to build their own mathematical ideas and concepts (mathematical concept formation). In a meaningful context, students can not only use their common sense to solve problems, but they can also use their personal mathematical theories.

The bold arrow in the middle separates the didactical framework into two parts, reinvention process at the top and the role of teachers in PMRI lessons at the bottom. The top part shows horizontal and vertical 'mathematisations'. Starting from contextual problems, students begin their mathematical concept formation by describing the problems using their own symbols and notations. In this process it is possible that each student has his/her own way of thinking. The vertical mathematisation also starts with contextual problems but, in the long run, the students can construct certain procedures that can be applied to similar problems directly, not necessarily using the context as a bridge. Gravemeijer (1994) calls this mathematisation of mathematical matter, as distinct from horizontal mathematisation, which is the mathematisation of contextual problems.

The part at the bottom corresponds to the teacher's role as facilitator and motivator in the learning processes. The role of the teacher is to create learning environments that provide students with rich learning experiences. This can only be done if the contextual problems satisfy relevance and familiarity conditions. These conditions will have an impact on student activity and interactivity. Teachers' knowledge of contextual problems and their ability to develop interactivity are important for successful learning, which subsequently supports students' mathematical concept formation.

The above framework, which provided the prototype of curriculum material for the teaching and learning of fractions in elementary education, was designed by means of the following sequence (Hadi 2006b) (Fig. 6).

As mentioned earlier, the materials were adapted from $\mathrm{MiC}$ curriculum materials which were not relevant to local contexts. In order to fine-tune them to Indonesian contexts and state-of-the-art Indonesian curriculum, the researchers appointed Indonesian experts as validators, an experienced mathematics educator and two primary school mathematics teachers. The components validated by those experts included the text format, learning activities and writing (Hadi 2006a) (Table 1).

The data collection instruments for this phase comprised questionnaire and interview. All three validators generally appraised the above aspects positively. For instance, the use of real context would enable students to build their mathematical knowledge and ideas through sequences of activities. Only a small revision was made to the draft of exemplary materials, i.e. making text format more userfriendly by adding explanation of the teacher's role in guiding students through the activities and the problems to be solved (Hadi 2006a).

After the design phase, the teaching experiments were conducted in two cycles. In this phase, the exemplary curriculum material was implemented and the extent to which the material supported the teaching and learning of

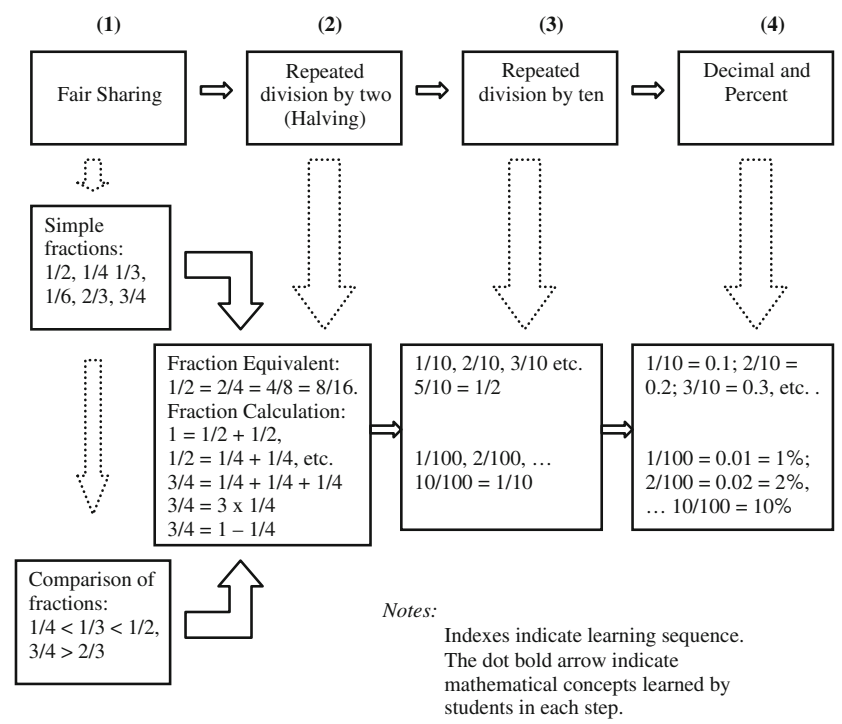

Fig. 6 Learning trajectory for fractions 
Table 1 Components validated in design phase

\begin{tabular}{ll}
\hline Components & Aspects \\
\hline Text format & 1. Parts are clearly identified \\
& 2. All pages have page-number \\
3. Font-type used is fine & 4. Font-size used is fine \\
5. The format is user-friendly \\
Learning & 1. Using the real-worlds \\
activities & 2. Enable students to use models to solve \\
& 3roblems \\
3. Using students' works \\
4. Enable students to build mathematical concepts \\
5. Promote interactivity \\
6. Intertwining between units \\
7. Promote students' reasoning and thinking \\
8. Promote reflection \\
9. Enable students to concentrate \\
10. Help students to negotiate problem solutions \\
1. Easy to understand \\
2. Explaining how to use the approach \\
3. Using good and correct Indonesian \\
4. Using simple and clear sentences
\end{tabular}

mathematics in accordance with PMRI principles. The teaching experiment phase in both cycles involved two primary schools in Banjarmasin-a public and a private school. The different traits of these two groups were seen to provide opportunities for the researchers to test and see how the material worked with different target audiences.

The experimental study showed the researchers how the exemplary learning materials worked in a classroom operating on PMRI principles-such as the use of real contexts, models, students' artefacts and interactivity. In the first schools it was conducted in two class sessions on 5 and 6 April 2005. In the second school, the experiment was held on 30 November 2005. The data were collected by means of observations, questionnaires and post-teaching interviews of teachers and students.

The following is a description of the results of the experimental study.

\subsubsection{Fair sharing}

There are many Indonesian contexts that are relevant to the concept of dividing a whole into equal parts, such as sharing bread (a square shape), bingka cakes (a special hexagonal shape), and bika-ambon cakes (a rectangular shape). In classroom activities, students may be divided into groups of 2, 3, 4 or 6. In the experiment, each group received a certain number of breads. In the activities they determined the portion that each student in the group should receive. Students' real-life experience in dividing a whole into equal parts helps them to relate formal fraction notations to their informal understanding of part-whole relations. In the learning process students also become involved in concrete activities, such as making, drawing or cutting out square and rectangular pieces of paper as representations of cakes, and then using these to divide a whole into equal parts. This activity also aids students in understanding part-whole relationships and the relationships between simple fractions.

\subsubsection{Repeated division by 2}

First students measured the lengths of different items in their classroom using paper strips (a measuring strip of any length made from a piece of paper). Their measurements had to be given in terms of 'strips'. If the length of an item they measured was not exactly the same as the strip or a multiplier of the strip length, students were encouraged to use halves and quarters, rather than whole units, by folding the measuring strips. This activity of measuring things using paper strips prepared students for 'Egyptian fractions'. Teachers could devise problems to help students make connections between the concrete paper strips and the symbols in the Egyptian fractions. The oldest system of fractions used by Egyptians was based on halving (dividing by 2).

\subsubsection{Repeated division by 10}

The second system of Egyptian fractions involved repeated division by 10 . Students examined circular diagrams that showed different fractions of a whole revolution. In ancient Egypt symbols were developed and used to describe what fraction of a whole turn was shown on each wheel. The wheel became a model of a fraction clock or fraction circle. In the present experiment, students divided a tenth of a wheel into tenths and thus each tenth of a tenth was one one-hundredth. They then divided a hundredth of a wheel turn into tenths, thereby discovering thousandths. Although this number system was similar to the standard decimal system, it did not presuppose the concept of place value.

\subsubsection{Decimals and percentages}

Prior to the introduction of the concept of percentages, teachers introduced the decimal notation that $1 / 10$ equals $0.1,2 / 10=0.2$, etc. Then teachers used students' informal knowledge about percentages to introduce the relationship between fractions and percentages. For example, 50\% is the same as one-half, and $25 \%$ is the same as one-quarter. The teachers were not supposed, however, to show students how to convert percentages to fractions unless students themselves specifically asked for this. Students also learned 
the relative nature of percentages. For example, $50 \%$ of 20 , which is 10 , is not the same as $50 \%$ of 50 , which is 25 .

In the activity of sharing breads and bika-ambon cake, students tried to find out the solution using several strategies of how to slice the bread into several parts equally. Some of them used rulers (or other measuring tools) to make sure that the bread was equally sliced, and several others used approximations. Then students were invited to use their practical knowledge of slicing bread in a sequence of activities that involved them in cutting and attaching models of bread and bika-ambon cake made of coloured pieces of paper (see Appendix 2). With the use of sketch drawings, students planned their solutions by dividing the models using vertical, horizontal and diagonal lines; they then drew their solutions and made marks to find solutions to certain problems-for instance, who would get the most bread? During the activities, students worked on the idea of part and whole relations.

During the learning process, students were actively engaged in discussions with their friends, in groups of 4 or 5 (see Fig. 7 and Appendix 1), and with their teacher. If and when they encountered difficulties, their teachers tried to help them negotiate their way by asking guided questions. During a 2-h session which incorporated a break for lunch and midday prayers, some students enthusiastically worked on worksheets and did not seem to want to stop. They busily continued working on the problems until their teachers reminded them that they should have left. It hardly needs to be added that this would be most uncommon in the more traditional Indonesian mathematics classes.

In the first school, after the lesson on the second day, students were asked to write short comments. Students' written comments about the learning can be divided into two groups. Of the 39 students who experienced the lesson, 31 regarded the lesson as 'very good', and seven appraised it as 'good', while one did not make any comment. Most of them felt the learning was enjoyable and they never got bored even though the lesson extended over a relatively long period. The reason for their positive appraisal would appear to be the attractive and challenging activities they did during the lesson, and the simple learning tools (such as

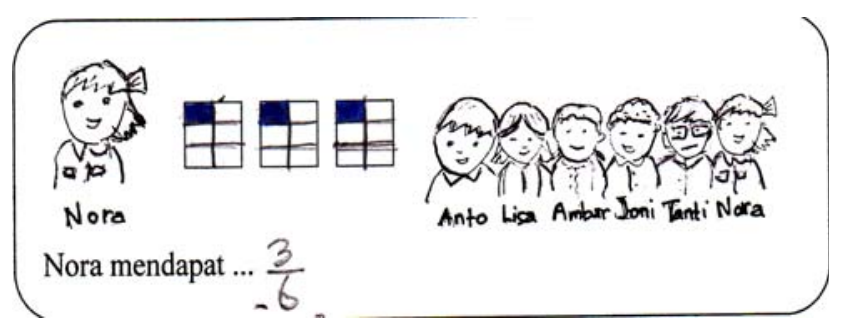

Fig. 7 Students in a group of 4 and a sample of their work scissors, pieces of paper, rulers, glue) that helped them easily 'grab' the ideas.

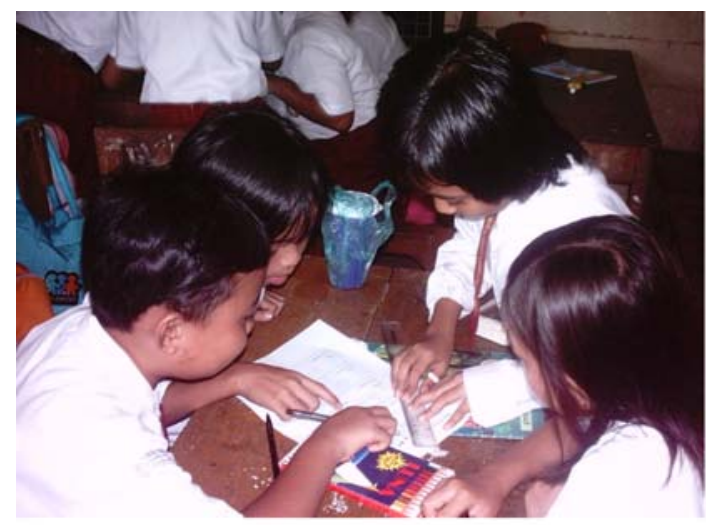

Rizkita : Well, how can we colour it?

Intan : If I am not wrong, from the earlier work that if we have three breads we can stacking them first then sliced into six parts, and each gets three out of six.

Rizkita: Yes, you are right!

In the second school, students' reaction to the lesson was collected by means of a questionnaire. The following Table 2 shows their reactions $(n=30)$.

Since the teachers were actively involved in developing the PMRI materials, they felt a sense of ownership and recognised that their students' classroom experiences with the materials helped them avoid standard difficulties. That appears to be a particular benefit of the bottom-up approach characteristic of the PMRI movement.

\section{Concluding remarks}

One of the first steps taken in implementing PMRI was the creation of a core team of experts on PMRI. In 2001, the PMRI team convinced the Directorate General of Higher Education (DGHE), four ITE and 12 primary schools to conduct an experiment. The first partial experiment was in grades 1 and 3 ( 6 and 8 years old). After an initial evaluation it was decided in 2002 to do a full experiment starting with first grade classes. The design and format of the experiment were constructed by the team in such a way that it was possible for teachers, textbook writers and other interested parties to provide input. From the beginning, Dutch experts on RME from the National Centre for School Improvement (APS) and the FI were consulted on the aims and design of the experiment. A formal first-phase cooperation with both APS and FI began with a grant from the Dutch government (2003-2005). The grant complemented Indonesian funding. In this first stage the primary goal was to conduct a pilot study involving grades 1, 2 and 3 , in 12 primary schools. 
Table 2 Students' reaction to the PMRI lesson

\begin{tabular}{lll}
\hline Questions & Students' answers & \\
\hline $\begin{array}{l}\text { Did you enjoy the lesson? } \\
\text { Did you find it easier? }\end{array}$ & Yes, I enjoyed it very much (90\%) & Yes, I enjoyed it (10\%) \\
$\begin{array}{l}\text { Were you involved in the lesson? } \\
\begin{array}{l}\text { Are you enthusiastic about what } \\
\text { you learned? }\end{array}\end{array}$ & Yes $(100 \%)$ & Not sure (6.7\%) \\
$\begin{array}{l}\text { Compared with your daily lesson, } \\
\begin{array}{l}\text { do you find this lesson more } \\
\text { interesting and easier? }\end{array}\end{array}$ & Yes $(93.3 \%)$ & No (10\%) \\
\hline
\end{tabular}

An independent evaluation of the first-phase cooperation can be found in the Report of Evaluation of the Bilateral Cooperation Program Indonesia (PBSI) (Dutch Ministry of Foreign Affairs, 2005). Among other things, the report states: 'It has become apparent that the project is more than the simple introduction of a new method of teaching mathematics. Although it has been officially stated in the initial project document, discussion with the project holders revealed that for them the introduction of 'realistic mathematics' is part of a broader attempt to change the educational culture at the level of basic education. Indeed the introduction of this method will affect the way students and teachers behave in the class and relate to each other. Without exaggeration, it can be stated that the project contributes to democratizing relationships in Indonesia and hence to social transformation.'

In January 2006 the DGHE appointed a new PMRI team. The new PMRI team consisted of the old team with some new faces. The DO-PMRI became a complex endeavour requiring the involvement and coordination of many government offices. At that time, the PMRI team created a development institution called IP-PMRI, with two main designate tasks to continue the experiment up to the sixth grade, and to disseminate PMRI on a larger scale. IP-PMRI managed to win a larger 4-year grant from the Dutch government through the NPT/NUFFIC project. The grant kick-started the second phase of the Indonesian-Dutch cooperation on PMRI, again with APS and FI being key players. This second-phase project is called DO-PMRI. The people involved in the project agreed that the main activities of the movement would be:

1. To build knowledge, skills and practices of primary teachers regarding PMRI.

2. To build knowledge, skills and practices of teacher educators regarding PMRI.

3. To institutionalise PMRI in the ITEs.

4. To institutionalise PMRI at a national level.

The NPT/NUFFIC DO-PMRI project activities focus primarily on the second and third of these objectives. Objectives 1 and 4 are mainly the responsibilities of the IP-PMRI team.

A bottom-up dissemination strategy is an essential characteristic of the movement. Elements of this bottom-up strategy are:
- Capacity building of the PMRI team and strengthening the ITEs by working closely together with teachers in pre-service and in-service teacher training.

- Developing teaching materials based on classroom experience and classroom research.

- Establishing an expanding network of local PMRI resource centres at each participating ITE, as startingpoints for further dissemination.

Currently there are 11 ITEs and $>30$ schools involved in the dissemination. These ITEs are expected to act as centres for the development and DO-PMRI in their respective regions. Their roles are to be institutionalised by the establishment of PMRI centres. These centres are places for teacher educators to carry out design research on PMRI. The creation of an Indonesian version of RME asks for instructional design or, even better, 'design research'. Design research assumes a scientific basis, and goes beyond the design of PMRI textbooks. It also takes into account the whole instructional setting, which includes instructional materials, tools, activities, interactions and classroom culture. This reflects the current perception that the design and use of instructional materials alone are too small a base from which to ensure curriculum innovation. Teacher educators from the respective PMRI centres are also expected to work collaboratively with teachers from their partner schools. They are expected to inspire, advise and support teachers trying to change their teaching style.

Workshop and follow-up activities for teachers are another element of the dissemination strategy. These basically encompass the following components: investigating and focusing instruction on a certain area of mathematics in primary school, designing instructional activities and experimenting with those activities in schools. Once mathematics teacher educators from PMRI centres have organised a start-up workshop, they continue with activities in which they help teachers to implement the PMRI approach in their classroom practice. The teacher educator will also compose portfolios of their various experiments and activities in their partner schools, and use these to frame interesting findings and questions, which could be a topic for discussion in subsequent workshop sessions. A mathematical-didactical exploration of various primary-school 
topics is one of the main themes of these workshops. This is valuable for teacher educators and in-service teacher education, primarily because the participants learn something that is related to their work as teachers. It is also beneficial for the ongoing bottom-up instructional design activities that take place in the context of PMRI. This general strategy underpins all planned activities, as well as decisions that have to be made during the execution of the project.

Demand from schools to implement PMRI is high and beyond IP-PMRI's ability to cope. As the movement spreads, it becomes necessary to define what is PMRI and what is not, and how to maintain the integrity of the concept. There is a great temptation to disseminate PMRI simultaneously nationwide. If, however, we have learnt anything from the history of the implementation of modern mathematics in Indonesia, this temptation should be resisted.

The challenge for the coming years is to preserve the characteristics of the movement, which are the key to success, during the dissemination activities that will take place. A model of training that is consistent with the PMRI model and that maintains the PMRI tenet still needs to be developed.

The Research and Development Office of the Ministry of National Education will assess the mathematical achievements of the PMRI experimental classes against those of parallel classes from the same school.

Open Access This article is distributed under the terms of the Creative Commons Attribution Noncommercial License which permits any noncommercial use, distribution, and reproduction in any medium, provided the original author(s) and source are credited.

\section{Appendix 1: Learning activities}

Figures 8 and 9.

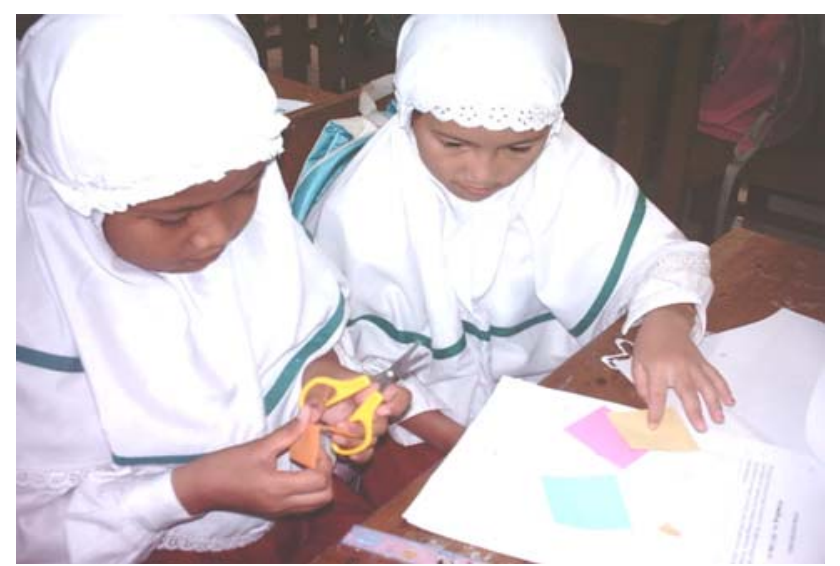

Fig. 8 Students working in a group — cutting and attaching models of breads

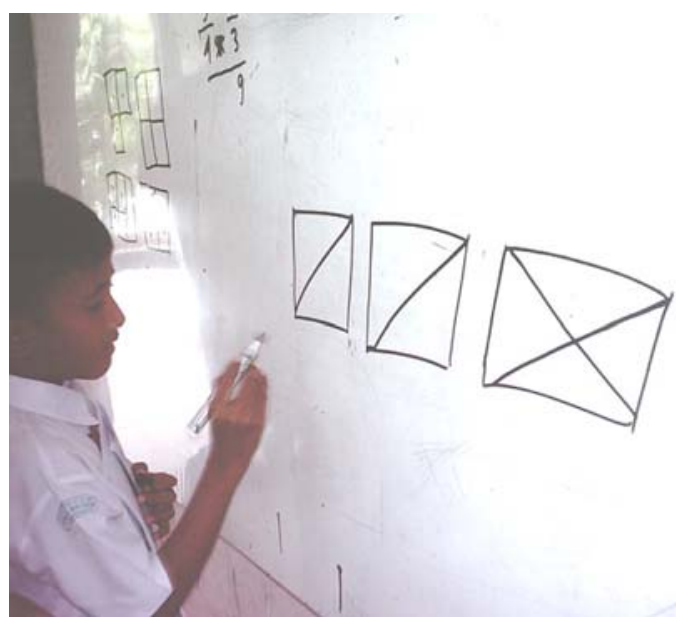

Fig. 9 Class discussion, a student comes to the board explaining solutions - three slices of breads divided by 4 , each gets $1 / 2+1 /$ $4=2 / 4+1 / 4=3 / 4$

\section{Appendix 2: Sample of students' work}

Figures 10 and 11.
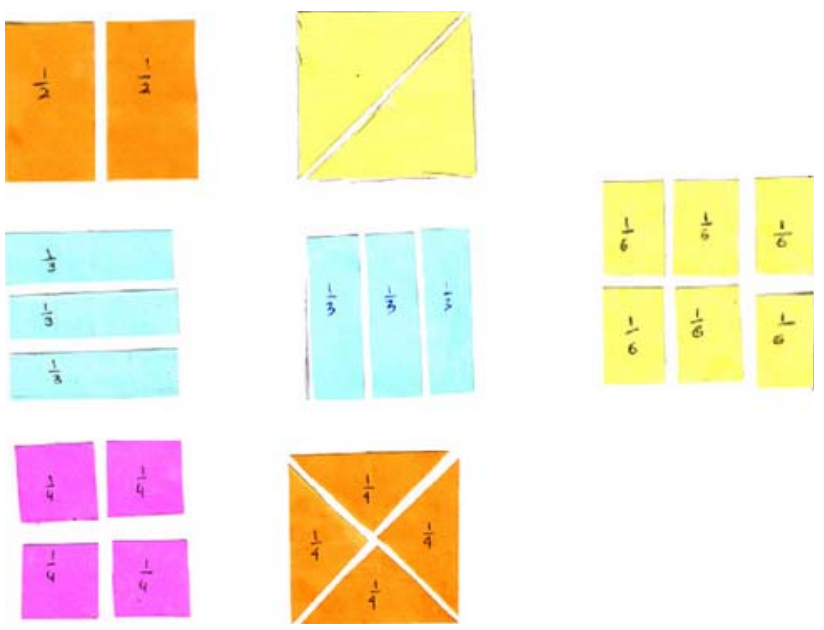

Fig. 10 Learning simple fractions
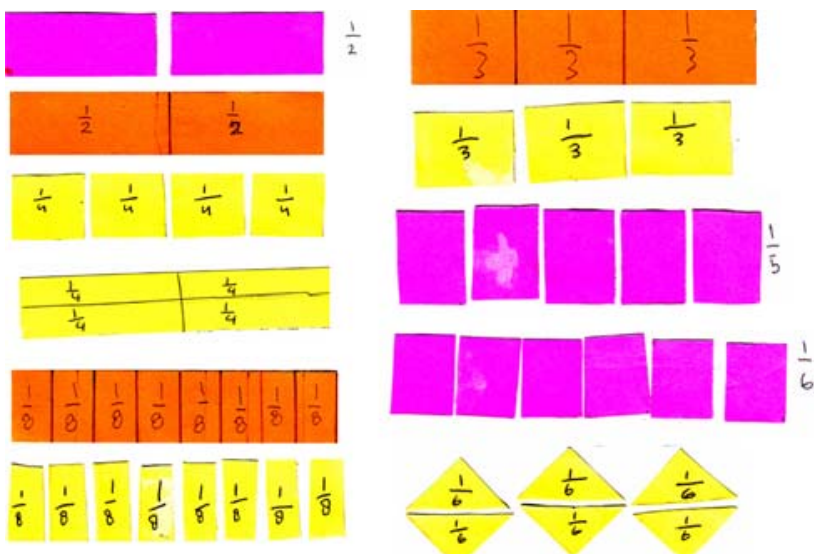

Fig. 11 Learning equivalent fractions 


\section{References}

van den Akker, J. (1999). Principles and methods of development research. In J. van den Akker, R. Branch, K. Gustafson, N. Nieveen \& $\mathrm{Tj}$ Plomp (Eds.), Design approach and tools in education and training (pp. 11-14). Dordrecht, The Netherlands: Kluwer Academic Publishers.

Armanto, D. (2002). Teaching multiplication and division realistically in Indonesian primary schools: A prototype of local instructional theory. University of Twente, Enschede: Doctoral dissertation.

Clarke, B., Clarke, D., \& Sullivan, P. (1996). The mathematics teacher and curriculum development. In A. J. Bishop, et al. (Eds.), International handbook of mathematics education (pp. 1207-1233). Dordrecht, The Netherlands: Kluwer Academic Publishers.

Cramer, K. A., Post, T. R., \& delMas, R. C. (2002). Initial fractions learning by fourth- and fifth-grades students: A comparison of the effects of using commercial curricula with the effects of using the rational number project curriculum. Journal for Research in Mathematics Education, 33(2), 111-144.

Depdikbud (1997). Statistik persekolahan 1995/1996. Jakarta: Depdikbud.

Dutch Ministry of Foreign Affairs, Department Asia, Oceania (DAO). (2005). Evaluation PBSI program. The Hague: BuZa.

Fauzan, A. (2002). Applying realistic mathematics education in teaching geometry in Indonesian primary schools. Enschede: Doctoral dissertation, University of Twente.

Freudenthal, H. (1973). Mathematics as an educational task. Dordrecht, The Netherlands: D. Reidel Publishing Company.

Freudenthal, H. (1991). Revisiting mathematics education, China lectures. Dordrecht, The Netherlands: Kluwer Academic Publishers.

Gravemeijer, K. P. E. (1994). Developing realistic mathematics education. Utrecht: CD- $\beta$ Press.

Gravemeijer, K. P. E. (1998). Developmental research as a research method. In J. Kilpatrick \& A. Sierpinska (Eds.), Mathematics education as a research method (Vol. 2, pp. 277-295). Dordrecht, The Netherlands: Kluwer Academic Publishers.

Gravemeijer, K. P. E. (1999). Developmental research: Fostering a dialectic relation between theory and practice. In J. Anghileri (Ed.), Principles and practice in arithmetic teaching. London: Open University Press.

Hadi, S. (2002). Effective teacher professional development for the implementation of realistic mathematics education in Indonesia. Enschede: Doctoral dissertation, University of Twente.

Hadi, S. (2005a). Pendidikan Matematika Realistik dan Implementasinya. Banjarmasin, Indonesia: Tulip.

Hadi, S. (2005b). The framework for the implementation of realistic mathematics education in Indonesia: Proceedings of the
International Conference on Applied Mathematics (ICAM05). Bandung, Indonesia: ITB.

Hadi, S. (2006a). Pengembangan materi pembelajaran pecahan berdasarkan pendekatan realistik. Jurnal Kependidikan dan Kebudayaan Vidya Karya, XXIV(1), 17-23.

Hadi, S. (2006b). Alur pembelajaran pecahan di Sekolah Dasar. Jurnal Pembelajaran, 29(1), 14-25.

Haji, S. (1994). Diagnosis kesulitan siswa dalam menyelesaikan soal cerita di kelas V SD Negeri Percobaan Surabaya. Tesis. Malang, Indonesia: IKIP Malang.

Jailani (1990). Suatu studi pengadaan terapan matematika pada siswa SMP Negeri di Kodya Yogyakarta. Tesis. Malang, Indonesia: IKIP Malang.

Kouba, V., Zawojewski, J., \& dan Strutchens, M. (1997). What do students know about numbers and operations? In P. A. Kenney \& E. A. Silver (Eds.), Results from the sixth mathematics assessment of the National Assessment of Educational Progress (pp. 87-140). Reston, VA: National Council of Teachers of Mathematics.

de Lange, J. (1994). Curriculum change: An American-Dutch perspective. In D. F. Robitaille, D. H. Wheeler, \& C. Kieran (Eds.), Selected lectures from 7th International Congress on Mathematics Education, Sainte-Foy, Quebec. Quebec: Les Presses De L'Universite Laval.

Manan, A. A. (1998). Langkah-langkah strategis ke arah pemecahan masalah peningkatan mutu SLTP. Kajian Dikbud, 014, IV. Jakarta: MoNE.

Mullis, I., Martin, M., Gonzales, E., Gregory, K., Garden, R., O'Connor, K., et al. (2000). TIMSS 1999: International Mathematics Report. International Study Center, Lynch School of Education: Boston.

Nasution (1996, May 27). Matematika sekolah menengah umum: persiapan menuju bahasa penalaran ilmiah. Kompas.

Romberg, A., \& de Lange, J. (1998). Mathematics in context: Teachers' resource and implementation guide. Chicago: Britannica Mathematics System.

Seels, B. B., \& Richey, R. C. (1994). Instructional technology: The definition and domains of the field. Washington, DC: Association for Educational and Communications and Technology.

Somerset, A. (1997). Strengthening quality in Indonesia's junior secondary schools: An overview of issues and initiatives. Jakarta: MOEC.

Tim Bina Karya Guru (2000). Matematika SD Terampil Berhitung, Jilid 4. Jakarta: Erlangga.

Widjaja, W. (2008). Local instructional theory on decimals: the case of Indonesian pre-service teachers. Unpublished Ph.D. thesis. University of Melbourne, Melbourne.

Zamroni (2000). Paradigma pendidikan masa depan. Yogyakarta, Indonesia: Bigraf Publishing. 